\title{
«An infinitely growing pact with oneself»: Novalis on the origin of philosophy
}

\author{
"Um pacto consigo mesmo, crescendo infinitamente»:
}

Novalis sobre a origem da filosofia ${ }^{1}$

FERnANDO MANUEL FerReIRA DA Silva ${ }^{a}$

\begin{abstract}
The present article seeks to inquire the nature of Novalis' difficult relation with philosophy. By founding this relation in a primordial spiritual conflict, wherein philosophy is the cause and the solution for the latter, as well as in an inescapable mythical understanding, wherein philosophy is at the same time necessary, and yet necessarily expendable, we intend to prove Novalis' own seemingly contradictory, yet infinitely productive concept of philosophizing: one where philosophizing is a ductile, organic way of dealing with the problem between the human being and the absolute. Furthermore, we wish to prove how this is most visibly considered in the sub-problem of the origin of philosophy, which sets the tone for Novalis' remaining philosophical edifice and inscribes him as one of the leading opposers of a systematic philosophy - and hence, as an advocator of the impossibility of attaining the absolute through philosophy.
\end{abstract}

Keywords: Novalis. Spiritual conflict. Philosophy. Origin. Necessity/need.

\footnotetext{
${ }^{1}$ The project leading to this application has received funding from the European Union's Horizon 2020 research and innovation programme under the Marie Skłodowska-Curie grant agreement No 777786.

a Universidade de Lisboa, Centro de Filosofia, Lisboa, Portugal. Doutor em Filosofia, e-mail: fmfsilva@yahoo.com
} 


\section{Resumo}

O presente artigo procura questionar a natureza da difícil relação de Novalis com a filosofia. Fundando esta relação sobre um conflito espiritual primordial do qual a filosofia é causa e solução, bem como sobre um entendimento mítico do problema, segundo o qual a filosofia é a um tempo necessária, e porém necessariamente dispensável, queremos comprovar a natureza aparentemente contraditória, e no entanto infinitamente produtiva do conceito de filosofar novaliano: a saber, como o filosofar surge como um modo dúctil e orgânico de abordar o problema entre o humano e o absoluto. Para além disso, propomo-nos provar como isto é mais visivelmente considerado no sub-problema da origem da filosofia, o qual dá o mote fundamental para o resto do edifício filosófico de Novalis e inscreve o seu autor como um dos maiores opositores a uma filosofia sistemática $-e$, portanto, como defensor da impossibilidade de alcançar o absoluto mediante a filosofia.

Palavras-chave: Novalis. Conflito espiritual. Filosofia. Origem. Necessidade/carência.

\section{The problem of philosophy: Philosophizing and its position in the construction of Novalis' thought}

Contrary to the belief of many critics, Novalis was indeed a philosopher and always thought and wrote on the nature of philosophy ${ }^{2}$. This is visible early on in his

\footnotetext{
${ }^{2}$ The first period of Novalis' philosophy, which indeed ends with his "Fichte-Studien" (179596), has been neglected to this day. The proof of this are Haussmann's texts on the reception of Novalis' work, which span between 1800 and 1900, in light of which it is not difficult to understand that very few works until 1900 even mention any aspect of Novalis' philosophical thought prior to 1795 (see HAUSSMANN, J. F., «German estimates of Novalis 1800-1850», in Modern Philology, Vol. 9, No. 3, (Jan. 1912), pp. 399-415, University of Chicago Press, 1912; and HAUSSMANN, J. F., «Die Deutsche Kritik über Novalis von 1850-1900», in The Journal of English and Germanic Philology, Vol. 12, No. 2 (Apr. 1913), pp. 211-244, University of Illinois Press, 1913). Indeed, even the exceptions to this, such as those of Dilthey (DILTHEY, W., «Novalis», in Preußische Jahrbücher 15, 1865, S. 596-650, or DILTHEY, W.: Das Erlebnis und die Dichtung. Lessing - Goethe - Novalis - Hölderlin, Göttingen, 1965 (Kleine Vandenhoeck-Reihe, Bd. 191), S. 187-241), Haym (HAYM, R., Die Romantische Schule. Ein Beitrag zur Geschichte des Deutschen Geistes, Berlin, 1870, pp. 324-390) or Schubart (SCHUBART, A., Novalis' Leben, Dichten und Denken. Auf Grund neuerer Publikationen im Zusammenhang dargestellt. Gütersloh, 1887), among others, do so in a notoriously biographical context, that is, aiming at analyzing the thinker Novalis, not Novalis the thinker, and hence never focusing on the author's philosophy - which leads to the conclusion that prior to the beginning of the previous century, not only Novalis' work had not yet acquired its due dimension, but Novalis had not yet been acknowledged his own philosophical thought as such. More Recently, (few) exceptions to this tendency have arisen. See FRANK, M., «Von
} 
life, in fragmentary texts composed between 1788 and 1791, such as "Von der Begeisterung” (1788) (NS I: 99-100); in several poems of a philosophical nature, composed during Novalis' early youth"; or in his "Fichte-Studien" (1795-1796) (NS II: 8-209), which is commonly accepted as the first expression of Novalis' philosophical thought.

However, Novalis' relation with philosophy was not an easy one. By vocation a poet, Novalis' coexistence with philosophical thought would be a painful one - a fact which is notable throughout his whole work, especially the philosophical one. Novalis' philosophical baptism, for instance, was a traumatic one, not without enduring consequences for the whole of his thought ${ }^{4}$; his constant labor on the dialect of the Graces appears to be - and was indeed — necessarily thorny, at times even anguishing, for undertaken in an hostile and strange territory (that of post-critical philosophy); and the ultimate end of such an enterprise, the search to harmonize the native and acquired tongues of the human being (the poetical and the philosophical ones), that is, a poetization of philosophy, would reveal to be an eversought, yet never truly attained task.

Now, upon searching for the cause for this phenomenon, Novalis' relation with philosophy only seems to prove the natural incompatibility between philosophy and poetry, and, as such, seems to be but one among many and inscribe Novalis' case among those of Friedrich Hölderlin ${ }^{5}$ or Friedrich Schiller ${ }^{6}$. Yet, we do not believe

der Grundsatz-Kritik zur freien Erfindung. Die ästhetische Wendung in den »Fichte-Studien« und ihr konstellatorisches Umfeld», in Athenäum 8, 1998, pp. 75-95; HAERING, T., Novalis als Philosoph, W. Kohlhammer, Stuttgart, 1954; MOLNÁR, G. von, Novalis' >Fichte Studies،. The Foundations of his Aesthetics. The Hague, Paris (Stanford Studies in Germanics and Slavics, Bd. 7), 1970; PIXBERG, H., Novalis als Naturphilosoph, C. Bertelsmann, Gütersloh, 1928; GABEL, M., Überlegungen zum Erkenntnisbegriff in Fichtes Wissenschaftslehre von 1794 und in den Fichte-Studien des Novalis, München, Grin Verlag, 2013.

3 Examples of this are the poems "Geschichte der Dichtkunst" (NS I: 55-56), or "Orpheus" (NS I: 67-72).

${ }^{4}$ References to Novalis' philosophical and theological studies in Jena, in 1790, are understood here, in the first section of this text, as the first plane of Novalis' philosophical reflection.

${ }^{5}$ Hölderlin would describe philosophy as "a hospital where to every disgraced poet such as myself may honorably flee" (See GStA 6.1: 289). Furthermore, he would often state that "Philosophy is a tyrant, and I rather tolerate its yoke than submit myself voluntarily to it" (GStA 6.1: 203).

${ }^{6}$ According to Wilhelm von Humboldt, Schiller too suffered from an "apparent oscillation between poetry and philosophy, a lack of confidence in his poetic task" (Werke, II: 358). 
the case to be so simple. We believe that Novalis' case, as well as its singular difficulty, are, even among similar ones, unique; and that as such this question deserves not to be taken for granted, rather it should be seen from a point of view closer to the nature of the question, that is, one which not only does not deny the previous conclusions, but seeks to elucidate their cause and the complexity of Novalis' philosophical thought through a path beyond that of a natural antagonism between poetry and philosophy. Therefore, instead of merely admitting the difficulty, we ask why philosophy, and its practice, were something so difficult for Novalis; and, given that Novalis was also a philosopher, why philosophy was so necessary a difficulty for Novalis. For, according to our view of Novalis' relation with philosophy, philosophy and its complexity are indeed real; but these facts do not stem from causes as natural, or as obvious, as the ones indicated. Instead, these facts derive from prior, very important life circumstances ${ }^{7}$ which, in turn, would come to be reproduced, under this very problematic form, on the construction of Novalis' theoretical thought, and hence, it is our belief that until we inquire such circumstances, and their application on thought, we will have to confine ourselves to assuming such conclusions, instead of explaining them.

According to our opinion, these crucial theoretical-existential circumstances represent two planes underlying the comprehension of the necessary difficulty of philosophical thought. A first plane, not exactly problematizable, yet factual and hence noteworthy, is that of Novalis' spiritual conflict, which molds his original conception of the problem of philosophy and which therefore lays the grounds for the latter's future resolution by the poet. A secondplane is that of Novalis'philosophical application of the previous spiritual conflict: namely, the form that bis philosophical thought on philosophy, which is extracted from his spiritual conflict, assumes, and how the former attempts to solve the latter. This second plane, in turn, is the joint result of two dimensions of thought in Novalis: one, strictly theoretical, Novalis' reflection and construction of the problem (that which, according to Novalis, is the necessity of philosophy) and other, of a mere practical nature, the modulation of Novalis' thought at the hands of a mythical-gnoseological form of representation of the origin, the procedure and the end of philosophy (which would result in Novalis' notion of a

\footnotetext{
7 "Just as one's life is real philosophy, so is one's philosophy ideal life - living theory of life" (NS, II: 318).
} 
need for philosophy); two dimensions which are concomitant and must be proved reciprocally.

Let us then consider in greater detail the two planes of analysis of Novalis' philosophical enterprise.

The first plane consists of the acquisition of a primordial form of Novalis' philosophical thought. This primordial form arises not with the "Fichte-Studien" (17951796), but already in 1790-1791, during Novalis' theological-philosophical studies in Jena, and it is brought about by the crossing influences of several of Novalis' professors: Schiller's lectures on poetry, the post-critical philosophy of the Kantian Carl C. E. Schmid and Karl L. Reinhold's Elementary Philosophy. According to Novalis, in a letter to Reinhold (see NS I: 508-514), the previous influences, especially the critical-philosophical one by Reinhold himself, its problems and relevance for the future form of philosophy, had cast Novalis into a conflict of the spirit. Namely, a conflict between poetry and philosophy, visible in "follies and deliria" (NS I: 509) ${ }^{8}$, a "dispersion" (id.: 515,556) of the spirit, a "fever of the soul" (id.: 523) imbued with exacerbated sensibility and fantasy (so to say, of a poetic nature), improper of a rational (so to say, philosophical) state, which never again would abandon the young poet. The only solution for this problem of philosophy, for its extreme nature and disruptions, would be — Novalis states — striving for the exact opposite of this: the attempt to suppress such conflicting feelings, thus promoting a "decisive supremacy" of reason "over sensibility and fantasy" (id.: 513): namely, through the acquisition of "a more defined and solid direction" (ibid.): a "concentration" (id.: $583,588)$, a self-restriction or self-reclusion of the I, a "tacit regression to oneself" (id.: 531): a healing process which was by then already in motion - through the very study of philosophy — and which Novalis would always undertake throughout his life.

Such a spiritual conflict, we believe, is fundamental and hence models Novalis' relation with philosophy as well as his further philosophical thought; for it

\footnotetext{
${ }^{8}$ All citations, not only Novalis', but also from other authors, will be presented in a traditional manner (Abbreviation of work, Volume of work, number of page(s)). The abbreviation of each work cited finds correspondence in the final bibliographical section. All citations have been translated from their original German language into English and are of my own translation.
} 
brings about the prime, never again abandoned form of the poet's approach to philosophy. And yet, let it be noted, the reason why philosophy is such a painful difficulty for Novalis is not its natural antithesis regarding poetry or the fact that Novalis now realized that his life as a poet, upon being scrutinized by philosophy, was composed of feelings and thoughts not to be expected from a rational man. That is, what is truly difficult in the problem of philosophy is not that its solution, in its clash with a poet's life, was the appeal to a rational restriction, a process of selfcritique of the I - which it nonetheless is. Truly conflicting and anguishing for Novalis (the reason of being of Novalis' difficulty) with philosophy is rather that such a selfcritique of the I, which is set into motion by philosophy itself, as the cause of the problem, must have in philosophy and in that very self-critique the solution for its own problem! Namely, philosophy is here cause and solution, palliative of a problem which it itself represents: a problem which is so only because philosophy exists, and which may be solved only insofar as philosophy exists; which means that within this singularity philosophy must come to discover its own general task and destination. Hence, such a singular difficulty means that philosophy is at once harmful and beneficial: philosophy is the elixir for the illness that it itself harbors and hence it must be exercised and brought to the zenith of its problem, despite the suffering and the disturbance this may cause in its host — for therefrom shall arise the solution for its problem, as well as communion with poetry. Philosophy, in sum, presents itself here as a difficulty for Novalis. But it is no mere difficulty. Philosophy, as well as the self-critical procedure of the I, is for Novalis, as well as for the human being in general, an inescapable difficulty - understood here as a necessary evil. And this is, as such, the original form of philosophizing for Novalis, an original form of resistance, that is, of philosophy's union in disunion with itself and in its destination towards poetry: a form which, as we shall see, would prove fundamental regarding the whole of Novalis' philosophical thought and which could, on its own, explain the poet's uneasy relation to the act of philosophizing.

The second plane consists of the natural evolution, according to the previous rules, of Novalis' philosophical thought. Namely, from the original form of Novalis' philosophical thought and its necessary accentuation by Reinhold's and then Fichte's philosophies,

\footnotetext{
${ }^{9}$ See annotation 19.
} 
emerges the acting — real — form of this thought, Novalis' own philosophizing, which, in accordance with the necessarily and especially difficult process of selfcritique which it is, finds its main problem in the critical self-cognition or critical selfcomprehension of the I — the philosophizing on philosophizing - and its proof in the very attempt to solve the problem of philosophy. As such, then, one could say that according to Novalis, the fundamental tendency of the self-critique of the $I$ in general presupposes a self-comprehension of the $I$, and that both are to be undertaken in accord with the previous terms of the problem.

However, this plane involves a supplementary difficulty. This difficulty, not only for us but for Novalis himself, resides in the fact that one such analysis, the process of self-comprehension of the $\mathrm{I}$, is, as was said, the joint fruit of a double approach to the problem of philosophy.

First of all, the collocation of the problem of philosophizing, its origin, procedure and end, within a spiritual conflict motivated by philosophy itself; or rather, the dedication of a sub-plane of analysis to the problem of philosophizing within a problem which, as is visible, is in itself a problem of philosophy. This Novalis does by dividing the process of a self-critique of the I tripartitely: in an analysis to the question of the opposites, the minimal units of the self-comprehension of the I; an analysis to the question of human consciousness, the intermediate plane of the selfcomprehension of the I; and an analysis to the question of philosophy: philosophy which, as we shall see, will present itself to us in the same quasi-paradoxical yet infinitely productive attire which is that of something which is cause and solution for its own problem: namely, in its possible impossibility and hence as the final plane in the application of the problem of a self-critique of the I.

Secondly, and not unrelated to the general problem of philosophy, the inscription of the problem of philosophizing as described within an altogether different framework of thought, namely, a more ancestral, and bence truer ground of knowledge: the previously mentioned mythical-gnoseological plane of the question. In other words, the focus here is upon Novalis' view of the problem through a mythical point of view. From this, and its association with the philosophical evolution of the poet's thought on the problem, we hope to extract clues on the true essence and efficacy of philosophy in the fulfilment of its role; a vision which, if coherent, shall have to 
produce the singular and difficult truth of philosophy in the shape of the already alluded union in disunion and its relation with poetry.

Now, for all these reasons, we therefore conclude that there are several and very complex problems which precede the general conclusion of Novalis' difficult relation with philosophy, problems which, in truth, justify that difficult relation; and because this is so, the present essay cannot intend to thoroughly approach the problem underlying Novalis' opinion of philosophy; nor, on the other hand, to go through the previous sequence, namely: 1) Novalis' spiritual conflict; 2) prior, tripartite phase of construction of a self-critique of the I; 3) final consummation of the problem in the philosophical-mythical approach of the sub-problems of the origin, the procedure and the end of philosophy, all in one article. This would result excessive in the first case and insufficient in the second. But because the object of this article is to analyze Novalis' difficult relation with philosophy, and within the latter, more specifically, the problem of the origin of philosophy, then perhaps it is possible, even recommendable, that, by tacitly departing from such a spiritual conflict, which grounds the whole of Novalis' philosophy, as well as summarily — yet expressly from the previous phases of construction of Novalis' philosophical thought (II.1), we set out to approach only the last of these planes of analysis of a self-critique of the I, and hence, the last of the planes of resolution of the self-conflict of philosophy. Hence, our intent is to analyze the plane which consists of the maximum point in the Gordian knot of philosophy and presents philosophy as the possible impossibility of itself; and once here, to approach the problem of philosophy by the sub-question of the origin of philosophy; that is, to ascertain its reason of being, the necessity and need for its destination, thus opening it to that which is its insoluble problem. (II.2 and II.3)

\section{The theoretical-mythological plane of Novalis' philosophical thought}

\section{II.1. The problem of the origin of philosophizing}

Real philosophizing, the superior and last stage in the resolution of the problem of philosophy, is preceded by two prior ones: the problem of the fundamental 
opposites, which deals with the activities of feeling and reflection, and the problem of the consciousness of the $I$, precisely the composite of feeling and reflection. These, to be sure, precede the problem of philosophy. And hence, in Novalis' view, the problem of philosophy — the self-critique - presupposes the resolution of said prior problems; and, no doubt, both must contribute towards the task of solving the poet's spiritual conflict.

As we analyze the previous pre-problems of philosophy, we no doubt understand that they do not arise by chance. These problems - that of the opposites and that of human consciousness - derive from an accentuation of the conflict of philosophy, and, as such, an accentuation through these very lesser degrees of this problem. This had been the case with Reinhold, some years before, and was now the case with Fichte ${ }^{10}$, whose position on the self-creation and selfcomprehension of the I would rekindle Novalis' spiritual conflict and request from him the afore-described painful activity of philosophizing on philosophy.

Fichte's position on the opposites, and subsequently his position on human consciousness, which we here present as one, is clear. According to Fichte, the circle of action and self-comprehension of the $\mathrm{I}$ is composed of a single entity - the $\mathrm{I}$, or absolute identity. The $\mathrm{I}$ is the fruit of such a counter-position of the two original opposites, feeling and reflection, that, in the point of the original action of the I, a fusion, through their minimal degrees, takes place between the opposites, and reflection, so to say, incorporates feeling. As such, then, feeling and reflection may be mutually reduced to such an extent that from the two arises but one: one single direction in the circle of Being; and if this is the essential trait of the original action of the $\mathrm{I}$, that is, if the $\mathrm{I}$ arises from such a mutual, yet terminal reduction, then the subsequent course must also obey such rules, something which must be ensured by reflection, which though not suppressing feeling, at least omits it and allows it a

\footnotetext{
${ }^{10}$ Reinhold did so by resorting to the opposites of "beziehen" (refer) and "unterscheiden" (differentiate) (see B I: 194: "Consciousness is the ultimate ground, the fundament upon which the theory of the power of representation is expounded; the differentiation and reference of representation to object and subject taken as a fact, which I consider to be universally valid, is the basis of my system"); Fichte did so through subject and object; to this very groundbreaking attempt he devotes his "Eigne Meditationen über ElementarPhilosophie". In: FICHTE, J. G. Gesamtausgabe der Bayerischen Akademie der Wissenschaften. Hg. von Reinhard Lauth u. Hans Jakob, II 3, pp. 21-177, Stuttgart- Bad Cannstatt, 1965.
} 
merely logical, not a real validity. Hence — according to Novalis — this means that, in Fichte's view, upon being born, upon saying I for the first time, in the original action of the $\mathrm{I}$, the $\mathrm{I}$ is already born free of any resistance between opposites, free from interruptions or orientation points in the circle of Being, and instead it immediately experiences its own absoluteness: it is the absolute I, and hence endowed with absolute consciousness over its own circle, thus progressing in a straightforward, unique, uninterrupted direction from limited to unlimited ${ }^{11}$ : a predesigned path which might even be unknown to the I, but which it nonetheless senses and must come to acknowledge as the path towards the continuous legitimation of its absoluteness.

It is here, as a response to Fichte's challenge, that Novalis' problem with philosophy is definitively set into motion; and it is here that Novalis' definitive formulation of the question arises. Novalis' response to Fichte's position - as was alluded to in Section I. - is a triple one and emerges under the guise of different degrees in the comprehension of the I - different degrees in the preparation of Novalis' thought on philosophizing, or different degrees in the resolution of Novalis's spiritual conflict.

The first degree of self-comprehension of the I, regarding the problem of the opposites, aims at the total inversion of Fichte's perspective on the problem. Namely, according to Novalis, feeling and reflection, indeed the greatest of all the opposites which preside — and must preside — over human life, cannot be but one, rather they must preserve their autonomy; and, as such, the circle of the selfcomprehension (or self-critique) of the I must be composed of two independent directions, infinitely converging with and infinitely diverging from one another. This means, contrarily to Fichte's opinion, that 1) Feeling does not progress from limited to unlimited, and reflection from unlimited to limited, rather feeling progresses from unlimited to limited and reflection from limited to unlimited (see NS; II: 19): which means that the circle of the comprehension of the $I$ - i.e. philosophy - has not one, but two simultaneously contrary and concomitant directions. 2) This being a circle with two

\footnotetext{
${ }^{11}$ See "Aenesidemus, oder über die Fundamente der von dem Hrn. Prof. Reinhold in Jena gelieferten Elementar-Philosophie. Nebst einer Vertheidigung des Skepticismus gegen die Anmaßungen der Vernunftkritik" (W I: 1-25).
} 
directions, and two opposed but also compatible directions, then the original action, the real contact point between feeling and reflection, will have to be thought in regard to a second point of orientation in the circle, namely, an ideal consummation point between the illimitations of feeling and reflection: which means that the circle of the I has not one, but two orientation points; and that, upon being born, the I not only is not absolute, but he always struggles, through philosophy, towards that other point of orientation, in a real, not just ideal, search for its consummation; 3) The real and ideal contact points being points of union, but also points of disunion of the opposite, then the contacts between feeling and reflection cannot occur, in the real point, between mere limitations (minimums), and in the ideal one, between mere illimitations (maximums); which would still suppress one of the opposites. Instead, the real I must arise from a double limitation — taken as an intensification — of the opposing natures of feeling and reflection, in such a way that both opposites are at the same time validated but restricted - in a word, equal; and the ideal I must arise from the exact contrary of this, both opposites thus being kept in existence during the course of the I. Hence, the real I proceeds in dis-intensification until the point of its ideal consummation, and the ideal I proceeds conversely, thus eternally recommencing the process of the self-comprehension of the I, which for this is reason, is and must be infinite.

The second degree of self-comprehension of the $I$, regarding the problem of the consciousness of the $I$, is anchored on the previous one and departs from its general ground. More specifically, it is grounded on the idea that the opposites are divergent, as well as convergent, within the same circle; that is, that the opposites progressively resist each other and thereby mutually legitimize themselves, and that this is the most fundamental layer in a self-critique of the I. Now, what this means, in other words, is that Novalis believed that, according to his system, but not Fichte's, the opposites were not impermeable, nor were they closed upon themselves, rather, as the result of their convergent-divergent autonomy, they exteriorize and inhabit their respective opposite. Namely, even though the opposites are de facto irreducible, and this must be so (a disunion of the opposites), however, from an ideal point of view, their union and mutual reduction is not only possible but also necessary. This, according to Novalis, is achieved through the vision of each of the opposites, which must lodge itself in its antipode (union of the 
opposites); in a word, something as an opposition which must, and yet cannot take place, a union in disunion of the opposites. And if this is so, and if one such union in disunion is here at the basis of the resolution of the problem - as it had been at the basis of the problem itself, the spiritual conflict caused and solved by philosophy then such opposites must themselves give form to human consciousness, which, as a supervising instance of the circle of comprehension of the $I$, as the axis of a selfcritique of the I, can no longer assume any absolute traits, rather must see itself as a form of union and/or disunion between feeling and reflection. Namely, a consciousness which knows that the opposites are united and disunited in their procedure, and acts as the infallible pendulum between the two: now tending towards the ideal consummation of the I, now tending towards its real origin, thus itself embodying the progressive resistance which is expected of the $\mathrm{I}$ as a being of opposites. Precisely this is brought to word by Novalis when he says that "Consciousness is a Being outside of Being, within Being" (NS II: 10), namely, thereby presenting consciousness as a Being - an organic, heterogeneous, being, a being composed of opposites — outside of Being — whose opposites, its constituents, exteriorize from themselves, thus promoting a real yet progressive (ideal) resistance which is their mobile — within Being: for such opposites, though ideally, never really exit themselves, rather are one and ensure the certainty of the process of selfcomprehension of the I.

Lastly, such a venture of the self-critique of the I has a third and final stage, no longer a preparatory, rather a decisive one, which consists in the vision of philosophizing within a problem which is, as such, one of philosophy — and which, due to its final and superior position must prove, as well as be proved, by the two previous stages. Here, one could simply begin by saying that the problem of philosophizing arises as the natural outcome of a problem which is caused and yet is solved in philosophy; that this third application of the problem arises so late, and has special importance, for that very reason and that surely in it must arise the resolution of the two previous stages of the problem. Indeed, one could do this, for all these assumptions are correct. But merely assuming this would not bring us any closer to Novalis' concept of philosophy — and much less to that of the origin of philosophy. Instead, we believe we must indeed think Novalis' concept of philosophy, as well as 
its origin, regarding the previous steps — in their progressive heterogeneity; but we must do so not actively, and hence somewhat randomly, as the natural result of the latter, rather retroactively, in the shape of a further delving into their theoretical kern; something which will undoubtedly influence our own view of Novalis' original spiritual conflict.

The analysis of this final stage shall then focus on philosophizing and its role in the self-comprehension, the self-critique and the view of itself in general of the $I$; and it is inaugurated here by the problem of the origin of philosophy, its respective connection with the inception of the I and its natural reflexive or speculative intimacy with human subjectivity. Let us then analyze this problem, approaching it now from the point of view of the necessity that it arises (II.1), now from the point of view of the need that it arises as it does, and that it is solved (II. 2).

\section{II.2 The necessity of the origin of philosophy}

The problem of philosophy starts with its origin; namely, the moment of the origin of philosophy in the I. According to Novalis, in the group of fragments collected under the designation "Vorarbeiten” (1798) (NS II: 312-424), “(...) the beginning of philosophy [is] a first kiss" (id.: 331). The description is reiterated once again in the same work: "The first kiss is (...) the beginning of all philosophy — the origin of a new world - (...) the fulfilment of an infinitely growing pact with oneself' (id.: $329)$.

Novalis' words recall other words by his own hand, according to which the act of philosophizing, or thinking, always bears something of the order of affectivity. Philosophizing, Novalis adds, is the supreme act of self-love, and this explains why philosophy is described by the poet as a "pleasure" (id.: 314), an "amorous caress" (ibid.) but also as an "embrace of the self" (id.: 329) or even a "matrimony" (id.: 329); for philosophy is the sweet, affectionate contact of man with itself and hence it is equally faithful to it as its bride; it is "the act of manumission - the clash against ourselves" (id.: 313), the "self-penetration of the spirit" (id.: 316), a "soliloquy of a superior kind" (id.: 320), a "self-revelation" (ibid.), a "pact with oneself" of the I 
(id.: 329) - for philosophy is always I, and the I is always philosophy. In a word, then, philosophy is the very first but also the last act of the I's self-love, for it exists in relation to the Being, and in relation to it only, insofar as it, as well as the I, are here in an intimate relation of self-analysis.

Now, the previous conception of philosophy is in full accordance with the previous strata of the problem of the comprehension of the I, as it is proposed by Novalis. The reason for this is simple. Regarding the first stratum - the level of the opposites - the result of its analysis is that feeling and reflection, the two hemispheres of the circle of Being, must be united and disunited, and that they must be so in such a way that in the circle there is a real original point and an ideal consummatory point. Now, the real original point is the point of the original action of the I - the point of the final feeling of human self-activity; and if this point represents the maximum union in disunion between feeling and reflection, and if both thus preserve their identity, then this not only means that the first action of the I is one of reflection, and hence philosophy, but it means that philosophy itself must also come to possess something of the feeling which participates in its inception and brings about its origin. Namely, in other words: philosophy is the first kiss, but at the same time, what is equally important, it is the first kiss of the I. Philosophy is the first kiss because through it the I first says I, thus tearing itself free from the passivity of an eternal contemplation of itself. Philosophy is the I as well as the construction of its own thought, its own image - its selfcritique — and hence, just as philosophy arises with the first subjective thought, with the first manifestation of the I's identity, so must the course of the I's thought go hand in hand with its philosophizing, and one's purpose will have to influence the purpose of the other. But, as such, philosophy is also a kiss because, upon being born, philosophy immediately acknowledges itself in formation of its own hemisphere and in directly inverse composition of another hemisphere; and hence, philosophy is here logical, it is here machine, infallibility, pre-designation, as in Fichte. Yet with this small (yet great) difference: that, according to Novalis, since it arises from a reciprocal mensuration, the union in disunion of the opposites, then philosophy must be not only reflection, but also feeling, not just rigorous machinelike progression, rather also affection, memory, regression (in a word, the basic components of Novalis' spiritual conflict): and hence, upon coming to be, 
philosophy tends to reflect and that is half of its self-critical nature, but, at the same time, philosophy acknowledges itself as part of a greater whole, a circle of Being, and as such something in it latches itself to feeling, something in it is affection and thus "manumission" (id.: 313), "self-penetration" (id.: 316); in a word, something in philosophy is as a kiss - but a kissing of oneself, to oneself: a kiss that stands for the I's self-love, which is more and more profound (critical), which is the mark of one's thinking of oneself and is the other part of a philosophical self-critique as it is understood by Novalis.

Furthermore, also in the stratum of thought which immediately precedes the one we are in - that of human consciousness - proofs may be obtained as to why philosophy is as it is and why Novalis describes it as a first kiss of the I. For Novalis' very fundamental notion of human consciousness — that of "a Being outside of Being, within Being" (NS II: 10) — seems to point to this. Namely, the vision of consciousness as "a Being" already bears the mark of organicity, of reciprocity, of progressive resistance of the opposites, of union in disunion which Novalis claimed for the problem and claims for his conception of philosophy. For consciousness, just as philosophy, is not a hemisphere, or a part of the Being, rather they are both hemispheres of the circle of Being, they are privileged expressions of the hybridity of Being. In turn, the vision of consciousness as a "Being outside of Being" brings about the order for the heterogenization which is that of philosophy, which, as an expression of the I's thinking on itself, is "the origin of a new world" (NS II: 329). And lastly, the vision of consciousness as a "Being outside of Being, within Being" brings about the final layer of Novalis' comprehension of the concept of philosophizing: that this is the kissing of oneself; that this is the opening to a new world, but a world of growing interiorization and self-penetration of the $\mathrm{I}$ in the I (for the $\mathrm{I}$ is in the Being, only divided in passivity and activity), until, through this progressive resistance of the opposites, this infinite oscillation of human consciousness, the I may again become Being. Hence, all this means that it is no mere chance that Novalis connects human consciousness to philosophy and interposes it between the latter's problem and that of the opposites: for, according to Novalis, consciousness too, as well as the I, arise with the original action, and hence along with philosophy; and as such, just as the original action too is partly visible reflection, partly occult feeling; just as it too is union in disunion, so must consciousness be part 
affection, part machine, and part self-affection, part self-management; and so does philosophy arise from this, so is philosophy precisely this.

In other words - and to sum up — we conclude that philosophizing is the necessary result, as it had been necessary cause, of the natural tripartite evolution of its own problem; and that the origin of philosophy is the origin of the selfcomprehension, cause and consequence of the problem of the I, within the circle of Being. It — the kiss that is the origin of philosophy — comes to be because it must be so; because the union in disunion of the opposites promotes it as such; because human consciousness, it too in oscillation, determines it as such; and because the selfcritique of the I, which is undertaken through philosophy itself, is of the order of a necessity. In a word, philosophy comes about because everything in the I converges for this to happen; and hence, it is also of the order of necessity that the I thus comes to be, and that through philosophy the I thus comes to think itself.

However, we ask here: where is the problem in a conception of philosophy which is completely necessary, which has its being in necessity and which, as such, so faithfully proves the preparatory states of its collocation - not to mention, that so flawlessly places philosophy and its necessity in the scope of a spiritual conflict wherein philosophy itself is the problem? And yet, at the same time, let it be noted: the idea of the opposites which must be united but cannot be united, i. e., which must be one in their difference, is surely a problem, but a solvable one, as was seen in II.1 through the alternating simultaneity of real and ideal visions of the problem (real disunion + ideal union). The idea of the opposites which compose consciousness is also a problem, yet a solvable one through the real disunion and ideal union of an I which is outside of itself within itself. But in the case of philosophy, the final expression of the I's thought, and its origin, how to consider its relation to an opposite? Is it necessary, or not, a union in disunion of philosophizing (a negative answer, of course, thus implying the latter's impossibility)? And if this is necessary, what consequences does this have for the I's thought?

Here is our view of the problem.

Itself the product of a union in disunion of the opposites and of a union in disunion of the conscious I, it cannot come as a surprise that philosophizing is also a procedure through opposites. To Novalis, the origin of philosophy means the opening of 
the I to reflection, to the speculative procedure between the self and the world and is hence a manifestation of the progressive resistance which grounds the poet's philosophical thought (on philosophy). Philosophy, one could even say, is to Novalis the very essential procedure of an I which is a being of opposites, which does not grant in itself any totalities or absolutes, and which as such excludes them from thought, from its own construction through thought, from the process of its selfcritique. All this is demonstrated by the joint nature of philosophy and the I, which hereby prove their uncoincidental intimacy, and are, as two factors of a unique self-forming force, one and the same. At the moment of its birth, however, philosophy is not informed of this destination merely by the fact that it arises from the double and simultaneous interaction of the opposites, and their hemi-circles of real or ideal influence, by the fact that it opens to its own pre-determined hemi-circle or by the fact that this hemi-circle has a pre-designed end and that end is in connection with its recommencement, and so forth. No. Quite on the contrary, Novalis suggests, none of this is instilled in philosophy and these are mere vicissitudes when compared with the true reason of being of the origin of philosophy. Namely, at its origin, philosophy is by nature imbued with a spirit of progressive resistance, and this not only explains its previous degrees of analysis, but determines its action - and here, precisely for this reason, renders it problematic. The cause for this difficulty is quite simple. For, first of all, one must bear in mind that philosophizing arises not from a minimum encounter between opposites, or the suppression of one in detriment of the other — as it does in Fichte — but, because such is its singular nature, philosophy has its origin in a maximum contact between opposites: which means that, because it departs from a maximum point, philosophy must progress by decreasing, by weakening itself, in dis-potentiation — in a word, as does a human being - until its final point; which, to be sure, is that of the ideal consummation of the I. And secondly, one must not forget that if philosophy tends from a maximum, that is, the original action of the I, towards a minimum, that is, the ideal consummation of the $\mathrm{I}$, then this not only determines the coordinating valences of philosophy, but leads us to subsume that philosophy has its golden age, its full form and vitality, in its origin — to be sure, until its origin and prior to it - and from then on, exists only to fulfil a destination: that of its management of the opposites, 
until, through the suppression of such opposites and its own subsequent rarefaction, or disappearance, philosophy may reunite, itself and the I, with the Being, in the ideal consummation point of its circle. That is, as it seems, philosophy is born only to fulfil one purpose: that of contrarily, hybridly, humanly progressing between extremities, extremities which now unite it, now separate it from its goal and hence are the image of philosophy's duplicity.

Therefore, one concludes, the problem is not so much in the phenomenon, but in the nature of the origin of philosophy: a nature which is eminently human, which no doubt is problematic due to its consonance with the traits of the previous problems, but which is so especially because, in the absence of an explicit opposite, philosophy must have its own beginning and end in itself, and hence it must be united and disunited with the only object that is real for itself: philosophy itself. Namely, the fact is that philosophy arises (cause of the problem); and it arises to consummate itself (solution of the problem): for philosophy is originated only so that, through this origin, the I's thinking of itself may progress towards its consummation. But, at the same time, because philosophy is its own opposite — and the course of Being is that of a circle — then philosophy progresses towards its consummation in order to be reborn (cause and solution of its own problem), for the consummation that philosophy envisages appears to be a death, but is also in truth life, under the guise of a return to the origin, to the non-existence, to the lack of philosophy, as if, by means of this, philosophy made an attempt at its own existence. And this, at last, seems to embody and put into practice the problem of the two previous stages of a self-comprehension of the I. Philosophy, one could then conclude, is indeed a necessary evil Philosophy is unique insofar as it holds itself as the palliative and the evil within itself, and in it coexist a simultaneous wish for death and a will to live which are always united and disunited in the I (which for the philosophizing means a very complex problem of incompatibility between the real and ideal directions of the destination of philosophy, and for the I means a Gordian knot which is never really undone). And hence, even if philosophy aspires to the end of its evil, or the end of itself, it only attains the infinite perpetuation of the latter, without which, to be fair, it would be something other than what it is and would cease to be. 


\section{3. The need for the origin of philosophy}

Finally, we have to consider the phenomenon, as well as the direct result, of philosophy's thorny resolution of its own problem. This, however, we shall do not by analyzing the very act of philosophizing in its announced and apparently paradoxical double tendency - which belongs to the problem of the procedure of philosophizing. Instead, we shall try to analyze that which grounds this: namely, the agglutination between necessity and need of (the origin of) philosophy, a belief which we do not hope from the very philosophical exercise of philosophy, rather is grounded on an altogether different wisdom which ascribes form to philosophizing and its problem and seems to legitimize, in Novalis' spirit as well as in other young thinkers, the previous spiritual conflict. Hence, we choose to see not how Novalis solves his problem, but to go to the root of Novalis' problem of the origin of philosophy.

When we cast our gaze beyond the phenomenon of philosophy, a different plane comes to light; a mythological plane, a plane of common, or communitarian wisdom, more archaic and grounding, which serves here as a theoretical ballast for times, opinions and beliefs. In it are grounded, more or less clearly so, the cultural events in general of all seasons; and German Idealism and Romanticism, Novalis', but also Hölderlin's, Hegel's, Schelling's time, not only had its own mythological reflection, but theirs is a singularly coherent and vivid one, so much so that it very often comes alive in their writings and binds them under a common spirit. Now, among the various vectors which compose the mythical background of Novalis' time, thus giving shape to the theory of those who summon it, is one in particular which would strongly influence the philosophical upbringing of all these authors. I refer to the biblical myth of the creation of the first man - and the loss of buman innocence (Genesis, Chapters I-III) - a myth which finds indirect correspondence in Greek mythology, namely, in Plato's conception of the divine creation and death of men (as expounded respectively in Timaeus and Gorgias) ${ }^{12}$. The content of such a common myth is, we

\footnotetext{
${ }^{12}$ These myths, with which each author was familiar for different reasons, exerted great influence not only upon Novalis (as shall be demonstrated below), but also upon Hölderlin, Hegel (as is shown by many of his theological writings between 1787 and 1793) and Schelling (as is proved by a series of myths Schelling collected and commented upon, as
} 
trust, widely known and requires no thorough explanation. Instead it is its application to man, to man's coming to consciousness, to his first thought of himself, to its language, in a word, to the question of philosophy, which is here truly important.

As such — and to summarize - that which unites myths such as those of the creation and death of humanity (and the human life thus created) is, first and foremost, the fundamental notion of a loss of unity as the result of a buman sin. In the biblical myth, for instance, it is said that in the garden of Eden there was peace and harmony, as well as infinite abundance, up until Eve's original sin; and that from this sin derives the inferior, human condition of Man's nature. In the Platonic myth, quite analogously, the problem begins when Zeus orders the Gods to create men in his image; and this by giving them a body and also something immortal and divine, the soul, through which men must always be impelled to acknowledge their aspiration to imitate the Gods. But if in their soul they are always pure, in their body men are dissimulated, they live in sin and at the time of their death they thereby conceal their flaws, which at once confirms the precariousness and the inferiority of their condition. Now, such myths, as well as their essential traits, are no doubt revived by the young idealists, who reenact them in light of their own comprehension of the theory of the I and its direct application: in philosophy. For, according to the idealists, there was once a time when the I and the world were one, when the words of men were so full of life that they themselves were objects; when the thought of man was so pure and untouched, that it was feeling; when, in a word, philosophy and religion lived in communion, or rather, they did not yet exist as such, rather were the faint manifestation of a world where there was but union and harmony, and man spoke poetry ${ }^{13}$. This time, however, is lost. And the end of such a golden age of man — so say the idealists - was the (self-)cognition of the $I$, or, in

documented in BUCHNER, H., (Hrsg.), "F. W. J. Schelling "Timaeus.» (1794)", Stuttgart-Bad Cannstatt, Frommann-Holzboog, 1994, and FRANZ, M., Schellings Tübinger Platon-Studien, Göttingen, Vandenhoeck \& Ruprecht, 1996. See also on this FRANZ, M., Tübinger Platonismus. Die gemeinsamen Philosophischen Anfangsgründe von Hölderlin, Schelling und Hegel, Tübingen, Francke Verlag, 2012.

13 "The blissful Unicity, the Being, in the unique sense of the word, is lost for us, and we had to lose it if we were to aspire and to fight for it" (GStA 3: 236); "Prior [to philosophy], men lived in a state of nature (...). Then, man was still one with himself and with the world surrounding him" (AS, I: 250). 
other words, that which is the seed of knowledge in the biblical myth, or the body which dissimulates and taints the soul in Plato's myth. For when man first said I and, as a subject, rendered himself his own object, he saw that his words were not the thing itself, he saw that religion is religion and philosophy is philosophy, he forgot poetry, of which, so says Hamann, there are now but "disiectae membra poetae"14, and turned inside, delving ever deeper into the cognition of himself, in a familiar process of self-critique. In a word, and to sum up, with the original action of the I takes place the original scission between the I and the object; with this scission begins philosophy ${ }^{15}$; and hence, with the origin of philosophy arises the I, which is also, as such, man's original sin, which forever marks man's condition and his subalternate buman nature. This is, therefore, the first mythical ground of the necessity of the origin of philosophy, and thereby is to be explained the necessity of the I's first reflection as well as the necessary specularity of this reflection.

In addition to this, however, something else unites the myths of the creation and death of humanity and its repercussion in the phenomenon of philosophy: namely, the notion, on the one hand biblical, of a divine punishment according to which man is saddled with the burden of forever having to try to expiate, in life, through himself, the guilty sin he himself committed; or the same notion, now

\footnotetext{
${ }^{14} \mathrm{~J} . \mathrm{G}$. Hamann's words: “(...) in nature we have nothing but jumbled verses [Turbatverse] and disiecti membra poetae left at our disposal. To gather these is the task of the erudite; to interpret them, the task of the philosopher; to imitate them — or still bolder! — to bring them to their destination, the modest task of the poet" (SDAN: 87).

${ }^{15}$ According to Novalis, "The first kiss is (...) the beginning of all philosophy - the origin of a new world - (...) the fulfilment of an infinitely growing pact with oneself" (NS II: 329). Hölderlin, in turn, says that: "Judgement. is, in its most elevated and rigorous sense, the original separation of the object and subject intimately United in intellectual intuition, that separation which first renders possible object and subject, the original division" (GStA 4.1: 226). As to Schelling, he states that "how is a world outside of us, a nature and with it experience possible, this question we owe it to philosophy, or rather, with this question arose philosophy" (AS, I: 250); and hereafter he adduces: "As soon as man was put in contradiction with the external world (...), the first step towards philosophy is taken. With this separation first starts speculation; henceforth, man separates that which nature had forever united, he separates object from intuition, the concept from image, and at last (insofar as he becomes his own object), he separates himself from himself" (ibid.: 251). Finally, Hegel also agrees that "The scission is the source of the need for philosophy" (HeW, II: 20), and thereby refers to a "dilacerated harmony" (id.), a "scission (...) from whence arises the system" (ibid.), a "supreme separation" (ibid.: 22) between "opposites rendered fix" (ibid.: 21). See also Hegel's words: "When the power of unification disappears from the life of men and the opposites lost their vivid reference and reciprocity and gain autonomy, that is when the need for philosophy is born" (HeW, II: 22).
} 
Greek in nature, of a necessity for buman retractation, according to which it is man's task, because he is the root of his own evil, to atone his sin by cleansing his soul and progressing towards a greater similitude with the Gods. Now, we reiterate once again, precisely the same notion is revived by the young idealists, who no doubt see in philosophy the original sin of human knowledge, but, at the same time, see in philosophy, in this singular manifestation of human expressivity and its internal feeling, something as a simultaneous possibility to annul the sin that is philosophy. Namely, the noteworthy notion here — the notion which indeed molds the thought of some idealists - is that philosophy, despite separating what was one, despite thus promoting the loss of the golden age of man, nonetheless is destined to annul its own sin, to extinguish human guilt, and this through its progress, but surely a progress understood as a restitution of the lost integrity of the origin ${ }^{16}$. In other words - and not unrelated to Novalis' previous position on philosophy and its origin — philosophy is demanded to return to the origin, or the golden age, of man; philosophy is demanded to undo, through itself, its own error. Which, however, must mean a singular course, contrary to that which seemed to be its natural one: namely, first of all, a philosophy which must progress towards its consummation to expiate its fault, and yet, a philosophy which must regress to its origin to expiate its fault — for origin and consummation, we reiterate, are but one; and secondly, a philosophy which, between both the tendencies of its singular course, must necessarily decrease in intensity, must fade away or suppress itself, for precisely this is expected of a philosophy which is born to die ${ }^{17}$. This, according to Novalis, is therefore the second mythical ground for the necessity of the origin of philosophy: that philosophy must aspire to die so that it can live; and that it must live so that it can aspire to die.

\footnotetext{
${ }^{16}$ In Schelling's own words: "It [philosophy] departs from that original separation to, through freedom, again unite that which in the human spirit was originally and necessarily united, that is, to suppress that separation once and for all" (AS, I: 252); or Hegel's: "To suppress such opposites rendered fix is the only interest of reason. (...) [The] totality is only possible, in the supreme form of life, through the reestablishment of supreme perfection" (HeW, II: 21-22).

${ }^{17}$ Novalis's words: "The genuinely philosophical act is suicide" (NS, II: 223). A conviction which is shared by Hegel: "(...) there is no truth of isolated reflection, of pure thought, but that of its annihilation" (HeW, II: 30), and also by Schelling: "philosophy labors (...) towards its own annihilation" (AA I.5: 72).
} 
Lastly, but still in this mythological plane of the question, our interest lies not only in the two grounds for the necessity of (the origin) of philosophy, but also in another ground, an even more fundamental one, which regards the need for philosophy. In it, we believe, resides the ultimate reason for Novalis' conception of the origin of philosophy, but also the reason for Novalis' anguishing yet productive relation with philosophy.

As such, in the two myths presented, the contents of both are perfectly identifiable. Both myths describe a mythical action which thereby models the way of thinking and feeling of human beings. But, let it be noted, maybe for this reason, when such an action is described it is presented as depicting not just any action, or thereby conveying an inane thought, rather as depicting actions and events which are not to be submitted to contingency, insofar as they themselves are at the origin of other events, and are themselves creative, not created from causality. Namely, such events, or truths, are of such a nature that they describe not something that could take place (as does probability), or had to take place (as does necessity), rather something that should take place; that is, not something dependent on circumstances, but something which is in the destination of things; not something historic, but precisely something mythical, which is eminently sensible, but whose truth, more pure and vivid than intellectual truth $^{18}$, is indeed beneficial for reason; and which, due to this, rather creates meaning, instead of being the product of meaning. Of this nature is, therefore, the need for the existence of the myth, which is always something much more pungent, but also more certain, than the necessity of reason.

Now, precisely something like this seems to be Novalis' opinion on the origin and the being of philosophy - a conclusion which we draw from the brief analysis to the two kinds of necessity of the myth of creation/death. For, regarding this, it is the belief of the idealists that philosophy does indeed part, once and for all, the original union; philosophy tears the I from its golden age and it is the origin of the evil that is itself; and, as such, philosophy itself must seek to atone that sin: it is philosophy, which is formed from and itself forms the opposites which constitute the I, which must try to surmount those opposites. But, beyond this, something else is suggested. For if philosophy is cause and solution of its own problem, and if to live it

${ }^{18}$ See Schelling, “De Malorum Origine” (AA, I.I: 108-109). 
must die and to die it must live, then perhaps one should think that, in the eyes of the I, philosophy does not only represent the cause and solution of its evil, or at least it is not so because it could or had to be so. Quite on the contrary, perhaps one should think that philosophy holds here a more fundamental role: namely, that of having to exist, as such and in these very terms, in the I, and hence having to legate these very buman traits to the I. Perhaps one should think, then, that it was always the destination of philosophy to be born, to have its origin and to part the I from itself; and it was always the destination of the I to be born, to live and to die as a being of opposites, and that, after all, this not only is not bad, or problematic, rather regards something which had to happen in favor of the I's ulterior good. Hence, if seen as such, the original division not only had to take place, rather it should take place — it had as its destination or was destined to - take place. And why is this? Precisely because it was the need of man that it lost its golden age and that he sought to regain it; and as such philosophy did not jut have to, rather it needed to arise, thereby dividing man; philosophy needed to aspire to reenact the golden age of man, thereby attempting to suppress itself and thus ceasing to be ${ }^{19}$; and philosophy needed to experience in itself, and to pass on to man, such traits of human fallibility and thus tend to die (philosophy as "a necessary evil" 20 . For, otherwise, without all these needs, man could never experience the feeling of loss, which always encourages him to progress in his destination and shows him the possibility of philosophy, despite the impossibility of philosophy; without these needs, man could never experience the hope of reacquiring an union with himself, which is always crushed and silenced by the fact that the progression of philosophy is also a return, and by the fact that philosophy is the maximum as well as the minimum degree of its own

\footnotetext{
${ }^{19}$ Schelling's words: "Philosophy must presuppose that original separation, for without it we would have no need to philosophize" (AS, I: 252); also Hölderlin's words: "We would have no presentiment of that infinite peace, of that Being, in the unique sense of the word, we would not aspire to reunite nature with us, we would not think and we would not act, absolutely nothing would exist (for us), even us would not exist (for us), if that infinite union, that Being, in the unique sense of the word, were present". Compare these words with these, in Hölderlin's Hyperion: "We now feel profoundly the restriction of our being, and the benumbed force fights impatiently against its chains, and yet there is something in us that prefers to maintain these chains - for were the divine in us restricted by no resistance, we would know nothing outside of us, nor would we know of ourselves, and to know nothing of oneself, not to feel oneself, and to be destroyed, is for us one and the same thing." (GStA 3: 194).

${ }^{20}$ See AS I: 252.
} 
problem. In a word, without these needs, man would never progress, he would be devoid of an end to his thought and his action and he would live forever equal, forever confined to himself in his own immutability.

\section{References}

FICHTE, J. G. Gesamtausgabe der Bayerischen Akademie der Wissenschaften. Hrsg. von Reinhard Lauth, Hans Jacob, Hans Gliwitzky und Peter K. Schneider. Stuttgart: FrommannHolzboog, 1962-2012.

FICHTE, J. G. Fichtes Werke, 11 Bde. Hrsg. von Immanuel Hermann Fichte. Berlin: Walter de Gruyter, 1971. (W)

HAMANN, J. G. Sokratische Denkwürdigkeiten. Aesthetica in nuce. Hrsg. von Sven-Aage Jørgensen. Stuttgart: Reclam Verlag, 1998 (SDAN).

HEGEL, G. W. F. Werke in 20 Bänden, auf der Grundlage der Werke von 1832-1845 neu edierte Ausgabe. Red. von Eva Moldenhauer u. Karl Markus Michel. Suhrkamp: Frankfurt am Main, 1986. (HeW)

HÖLDERLIN, F. Sämtliche Werke. Grosse Stuttgarter Ausgabe (15 Bde.). Hrsg. von Friedrich Beissner. Stuttgart: W. Kohlhammer Verlag, 1966-1969. (GStA)

HUMBOLDT, W. von. Werke in fünf Bänden. Stuttgart: Cotta, 2010. (Werke)

NOVALIS, Schriften. Werke, Tagebücher und Briefe Friedrich von Hardenbergs, hrsg. von HansJoachim Mähl u. Richard Samuel (3 Bde.). Darmstadt: Wissenschaftliche Buchgesellschaft, 1999. (NS)

REINHOLD, K. L. Beiträge zur Berichtigung bisheriger Missverständnisse der Philosophen. 2 Bde. Hamburg: Felix Meiner Verlag, 2003. (B)

SCHELLING. Historisch-kritische Ausgabe, im Auftrag der Schelling-Kommission der Bayerischen Akademie der Wissenschaften. Hrsg. von Jörg Jantzen, Thomas Buchheim, Jochem Hennigfeld, Wilhelm G. Jacobs und Siegbert Peetz, 40 Bde. Stuttgart: FrommannHolzboog, 1976ff (AA).

SCHELLING, F. W. J. Ausgewäblte Schriften in 6 Bänden. Hrsg. von Manfrd Frank. Suhrkamp: Frankfurt am Main, 1985. (AS)

RECEIVED: 02/27/2019

APPROVED: 02/13/2020

RECEBIDO: $27 / 02 / 2019$

APROVADO: $13 / 02 / 2020$ 